\title{
„UNÁHLENÉ ZÁVĚRY“ U PSYCHOTICKÝCH ONEMOCNĚNII: PŘEHLEDOVÁ STUDIE
}

\author{
PETRA ŠUSTOVÁ, MABEL RODRIGUEZ
}

\begin{abstract}
Abstrakt: Tato přehledová studie popisuje nejčastěji zkoumané kognitivní zkreslení u psychotických onemocnění - unáhlené závěry. Toto zkreslení odkazuje k odchylce v usuzování, kdy jedinec dochází k úsudku na základě nižšího množství informací, než je běžné. Výzkumné studie popisují př́ítomnost kognitivního zkreslení napříč celým psychotickým kontinuem. Unáhlené závěry jsou nejčastěji zkoumány ve vztahu k bludům, existuje však diskrepance mezi výsledky metaanalýz a longitudinálních studií ohledně toho, jak spolu bludy a unáhlené závěry souvisí. Stejně tak dosud není jasné, jak spolu souvisí kognice a kognitivní zkreslení. Metodologie měření unáhlených závěrů je v současnosti velmi roztř̌iššená, což s sebou nese řadu problémů, kterým se v článku věnujeme. Poslední část je věnována možnostem a efektivitě tréninku metakognice, který by mohl vést ke snížení unáhlených závěrů a potenciálně $\mathrm{k}$ nefarmakologickému ovlivnění bludů a dalších pozitivních symptomů.
\end{abstract}

Klíčová slova: unáhlené závěry, psychóza, bludy, kognitivní zkreslení, schizofrenie

\section{"Jumping to conclusions" in psychotic illnesses: a review study}

Abstract: This narrative review describes the most frequently investigated cognitive bias in psychosis - jumping to conclusions. This bias refers to deviance in reasoning, when person reaches to the conclusion on the basis of less evidence than it is usual. Experimental studies describe presence of the bias across whole psychotic continuum. Jumping to conclusions is most frequently studied in associations with delusions. There are discrepancies between results of metaanalyses and longitudinal studies about the nature of relationship between those two phenomena. Relationship between cognition and this bias remains also unclear. Methodology of measuring the bias is very fragmented, and that brings a lot of problems descibed in the article. Last part is dedicated to posibilities and efectivity of metacognitive training, which could lead to decrease in jumping to conclusions and potentially nonfarmacologicaly influence delusions and other positive symptoms. Key words: jumping to conclusions, psychosis, delusions, cognitive bias, schizophrenia https://doi.org/10.14712/23366486.2021.7

\section{1. Úvod}

Unáhlené závěry jsou specifická kognitivní zkreslení, která se vztahují k procesu vyhodnocování informací a tvorbě úsudku. Jako unáhlené označujeme závěry, které byly utvořeny v situacích, ve kterých nemáme ještě dost informací na to, abychom mohli dojít ke spolehlivému rozhodnutí (Evans, Averbeck, Furl, 2015). V zahraniční literatuře se pro toto zkreslení používá pojem ,jumping to conclusions“ (JTC). 
Toto zkreslení bývá nejčastěji zkoumáno v souvislosti s psychózou a především s bludy. Autoři vůbec první studie unáhlených závěrů u schizofrenie vycházeli z výzkumu rozhodování a konzervatismu u zdravé populace (Phillips, Edwards, 1966) a navrhli úlohu na měření pravděpodobnostního usuzování, ve které se sleduje množství informací, které člověk potřebuje k tomu, aby si utvořil úsudek (Huq, Garety, Hamsley, 1988). Již dř́ive studie zdokumentovaly ukvapenost usuzování u pacientů s bludy v úlohách, ve kterých byl využit podnětový materiál, vztahující se k obsahu bludů těchto pacientů (Brennan, Hemsley, 1984). Nově vytvořená úloha (Huq, Garety a Hamsley, 1988) však pacienty konfrontovala s neutrálním podnětovým materiálem, který se tematicky nevztahoval k jejich bludům - zaměřovala se tak šířeji na obecnou schopnost pravděpodobnostního usuzování. Od roku 1988, kdy byla tato studie publikována, výzkumy ukazují, že pacienti s psychotickým onemocněním, zejména ti, kteří mají aktuálně bludy, dochází k rozhodnutí po prezentaci menšího počtu informací než zdravé kontroly i ostatní pacienti s psychiatrickým onemocněním (Dudley et al., 2016). U zdravých kontrol unáhlené závěry korelují se subklinickou bludnou ideací (delusion proneness) (Ross et al., 2015), př́slušností k novým náboženským hnutím (Lim, Gleeson, Jackson, 2012) a paranormálními přesvědčeními (Irwin, Drinkwater, Dagnall, 2014).

Zatímco některé dřívější teorie bludů předpokládají, že bludy vznikají jako odpověd' na vnímané percepční anomálie (tedy jedná se o bottom-up př́stup), kdy jedinec potřebuje najít „racionální" vysvětlení pro zažívané abnormality (Maher, 2005), současné modely integrují jak bottom-up, tak top-down procesy. Např. Bryod et al. (2017) nahlížejí na vznik a udržování bludů jako na problém s přisuzováním jistoty (assessment of certainty), a to na dvou úrovních. Zatímco tzv. low-level certainty se vztahuje ke spolehlivosti vnímaných stimulů, high-level certainty reflektuje míru, s jakou jsme si jisti našimi přesvědčeními a zkušenostmi. Vzájemný vztah mezi těmito procesy si lze dle Bryod et al. (2017, s. 97) zjednodušeně představit tak, že ,zatímco bottom-up procesy nás vedou $\mathrm{k}$ tomu věrit tomu, co vnímáme; top-down procesy vedou k tomu, že naše vnimání je zkreslené či pozměněné dle toho, čemu věř́me. "Fenomén unáhlených závěrů, který pozorujeme u pacientů s bludy, spadá do oblasti top-down ovlivnění a reflektuje narušení v připisování jistoty na vyšší úrovni.

Obdobně na unáhlené závěry pohlížejí teorie vycházející z prediktivního kódování. Stěžejním procesem v těchto teoriích je tvorba inference - závěru o světě. Abychom mohli ve světě efektivně fungovat, vytváríme si na základě předešlých zkušeností predikce předběžná očekávání - která náš mozek porovnává s aktuálně dostupnými (povětšinou) senzorickými daty. Když tato data a naše očekávání sedí, utvrzujeme se v našem obrazu světa. Pokud predikce a senzorické informace neodpovídají, vzniká tzv. predikční chyba - část nevysvětlené informace, která, vzhledem k tomu, že inference jsou hierarchicky uspořádány, postupuje z nižší úrovně na vyšší. Pokud ve vyšších úrovních nedokážeme predikční chybu „vysvětlit“ $v$ rámci naší dřívější zkušenosti, dochází k úpravě zkušenosti. Integrace našich predikcí a predikčních chyb je ovlivněna také váhou, jakou jim přikládáme. U pacientů s pozitivními symptomy se předpokládá, že připisují velkou váhu predikčním chybám, které se pak z nižších úrovní propagují na vy̌̌ší, kde tak vzniká falešné přesvědčení. To pak ovlivňuje naše budoucí predikce (Friston, 2005). Dle Adamse et al. (2013) reflektují unáhlené závěry sníženou přesnost inferencí, která následně vede k větší důležitosti senzorických informací.

Cílem této přehledové studie je přiblížení současného stavu poznání v oblasti unáhlených závěrů u celého spektra psychotických onemocnění a možností jejich ovlivnění 
pomocí vhodných intervencí. Tato přehledová studie přibližuje současný stav poznání v oblasti unáhlených závěrů u psychotických onemocnění. Vzhledem k tomu, že v našem prostředí se jedná o dosud velmi málo diskutovanou oblast současného výzkumu u psychotických pacientů, stěžejní část článku je věnována metodologii zkoumání unáhlených závěrů. Dále se článek zaměřuje na souvislosti unáhlených závěrů s psychózou, bludy a neurokognicí. Závěrem chceme představit dva tréninkové programy, které se snaží $\mathrm{s}$ unáhlenými závěry terapeuticky pracovat, a inspirovat tak klinické pracovníky $\mathrm{k}$ jejich zapojení mezi další intervence doporučované u psychotických onemocnění.

\section{Metodologie zkoumání unáhlených závěrů}

Klasickou experimentální úlohu na zkoumání unáhlených závěrů představuje tzv. Beads task. Jedná se o úlohu, ve které jsou probandům prezentovány dvě nádoby naplněné korálky dvou různých barev. Barvy korálků jsou v každé nádobě zastoupeny v opačném poměru, tzn. v nádobě A je $85 \%$ červených korálků a $15 \%$ modrých, v nádobě B $85 \%$ modrých korálků a 15\% červených (viz obr. 1). Probandům je prezentována série korálků, které byly vytaženy z nádoby a jejich úkolem je rozhodnout, ze které nádoby jsou korálky losovány. Dále jsou informováni, že každý korálek je po vylosování znovu vrácen do nádoby, takže poměr korálků zůstává stále stejný. Po každém novém vylosování korálku, je proband dotázán, zda se již rozhodl, z jaké nádoby jsou korálky losovány, nebo zda si přeje nechat vylosovat další korálek. Série korálků je však předem dána, všichni probandi vidí tu stejnou sekvenci. Sledovanou proměnnou je počet korálků, které si proband nechal ukázat předtím, než došel k rozhodnutí (Evans, Averbeck, Furl, 2015).

Od doby, kdy byla publikována první studie na pacientech se schizofrenií (Huq, Garety, Hamsley, 1988), bylo vytvořeno množství alternativních variant této úlohy. Vzhledem k tomu, že klasický beads task bývá označován jako př́liš abstraktní úloha, vznikly úlohy, které manipulují s konkrétnějšími podněty. Rozšiřrená je např. varianta, kde jsou místo

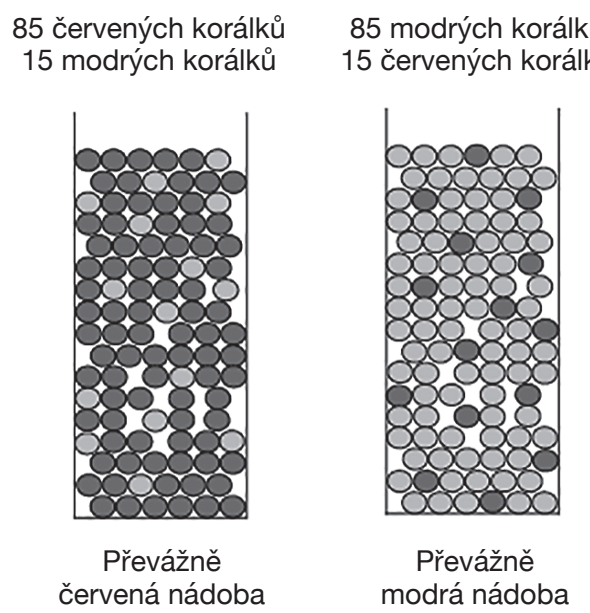

Obr. 1: Beads task, upraveno dle popisu v Huq et al. (1988). V původní studii šlo o modré a červené korálky, na našem obrázku jsou to tmavé a světlé korálky. 
korálků ovce. Probandi vidí dvě stáda ovcí, ve kterých jsou černé a bílé ovce zastoupeny v opačném poměru, a mají uhodnout, ze kterého stáda se ztratila prezentovaná série ovcí (Moritz et al., 2016). Velmi populární je také tzv. fish task, kde je cílem probanda uhodnout, ze kterého jezera loví rybáŕ ryby (v každém jezeře převažuje jedna barva ryb) (Speechley, Whiteman, Woodward, 2010). Existuji také tzv. emočně salientní verze beads task, ve které se místo nádob s korálky prezentují dva průzkumy o vlastnostech nějaké osoby. V prvním průzkumu je dotyčná osoba vykreslena pozitivně, v druhém převládají negativní charakteristiky. Úkolem probandů je vybrat, ze kterého průzkumu pochází série komentářů popisujících vlastnosti dané osoby (Young, Bentall, 1997). Experimentuje se také s poměrem informací $\mathrm{v}$ úloze. Nejčastěji se používá poměr $85: 15$, který byl použit v originální studii Phillipse a Edwardse (1966). Poměrně rozšiřená je však i tě̌̌ší varianta 60:40, často se ve výzkumech zadávají společně. Některé studie využívají vlastní poměry např. 80:20, což znesnadňuje interpretaci výsledků (Balzan, Delfabbro, Galetlly, 2012). Ukazuje se, že čím je úloha náročnější (60:40), tím více souvisí výkon v úloze s úrovní kognitivních funkcí (především pracovní pamětí) (Krężołek et al., 2019).

Nejednotná však není pouze podoba a poměr používaný v experimentálních úlohách, ale i způsoby vyhodnocování úlohy. Nejčastěji studie při vyhodnocování pracují s tzv. draws to decision (DTD) - počtem korálků (informací), které si proband nechal prezentovat před tím, než se rozhodl. Tato metoda je nejcitlivější k rozlišení pacientů s bludy a bez bludů (Fine et al., 2007). Dalším parametrem, který se často sleduje, je tzv. JTC bias, což je procento respondentů, kteří vykazovali extrémní odpovědi (většinou definováno jako rozhodnutí se po 1-2 prezentovaných informacích) (Evans, Averbeck, Furl, 2015). Další metodou je přiřazování pravděpodobnosti (tzv. probability estimates procedure), kdy po prezentaci každého nového korálku odhadují probandi pravděpodobnost, s jakou vylosovaná sekvence pochází z nádoby A, nebo B (Moritz, Woodward, 2005). Kombinací této a DTD metody pak je tzv. graded probability estimates procedure. Úkolem probandů je po každém prezentovaném korálku vybrat jednu z možností na sedmibodové škále, jejíž konce jsou označeny jako „rozhodně pochází z nádoby A“ a „rozhodně pochází z nádoby $B$ “. Uprostřed se pak nachází možnost ,ještě se nelze rozhodnout“. Pokud proband vybere jednu z krajních odpovědí (rozhodně z nádoby A/rozhodně z nádoby B), je tato volba vyhodnocena jako rozhodnutí (Young, Bentall, 1997).

Ačkoli ve výzkumu hojně využívaná, úloha beads task se jeví jako velmi problematická. Dle studie Balzan, Delfabbro a Galetlly (2012) lze horší výkon v úloze u pacientů připsat spíše neporozumění zadání než tendenci činit unáhlené závěry. Někteří autoři také upozorňují na fakt, že pravděpodobnostní usuzování dělá problémy nejen pacientům, ale lidem obecně, a odkazují se na známé experimenty Kahnemana, ve kterých se většina respondentů rozhoduje jako špatní statistici (Maher, 1974). Jiní autoři zase zmiňují jako původce rozdílu mezi zdravými kontrolami a pacienty kognitivní deficit, zejména obecné problémy s abstrakcí a pracovní pamětí u pacientů (současný stav poznání v této oblasti je blíže popsán níže) (Freeman et al., 2014).

$Z$ výše zmíněných důvodů vznikla potřeba vytvoření nové úlohy, která by měřila stejný fenomén, ale jiným způsobem. Vznikla tak nová úloha, tzv. box task. Respondentům je na počítači prezentována obrazovka s několika „,boxy“, které mohou probandi kliknutím otáčet, aby zjistili, jaká barva se pod nimi skrývá. Respondenti vždy vidí informaci, v jakém poměru jsou obě barvy zastoupeny (Moritz et al., 2017). Studie se však rozcházejí v tom, zda výsledky v této nové úloze korelují s výsledky v beads task (Chu, Sun, So, 2015; Moritz 
et al., 2017), či nikoliv (Balzan et al., 2017). Jsou však zapotřebí další výzkumy, které by ukázaly, zda úloha box task zachycuje skutečně tendenci k unáhleným závěrům a lze ji používat ve výzkumu místo beads task, či zda ve skutečnosti zachycuje jiné zkreslení.

Kromě experimentálních metod se ve výzkumu kognitivních zkreslení používají i sebeposuzovací dotazníky, které zachycují větší počet kognitivních zkreslení najednou. Jejich výsledky však mohou být zatíženy vysokými nároky na schopnost sebereflexe a soustředění, což jsou oblasti u pacientů často oslabené.

Cognitive Bias Questionaire (CBQ) (Peters et al., 2010) je dotazník mapující kognitivní zkreslení typická pro psychózy (resp. bludy u psychóz). Vznikl na základě dotazníku Cognitive Style Test (Blackburn, Jones, Lewin, 1986), který se používá k měření kognitivních zkreslení u deprese. Skládá se z popisu 30 událostí z každodenního života, u kterých si respondent volí jednu ze tří možností, která nejlépe vystihuje to, co by ho v dané situaci pravděpodobně napadlo.

Př́iklad položky z dotazníku CBQ vztahující se k unáhleným závěrům:

Představte si, že zvoní telefon. Zvednete ho a druhá strana okamžitě zavěsí.

Pravděpodobně bych si pomyslel:

A: Uvažuji, zda je na tom něco podezřelého. (2 body)

B: Někdo se mě určitě snaži kontrolovat. (3 body)

C: Někdo mél asi špatné čislo. (1 bod)

CBQ-P se snaží zachytit pět kognitivních zkreslení, kromě unáhlených závěrů to je dále dichotomické myšlení, katastrofizace, intencionalizace a uvažování založené na emocích. Odpovědi jsou skórovány 3-1, kde odpověd' s hodnotou 1 znamená absenci zkreslení, 2 prrítomnost zkreslení, které ale proband dokáže zpochybnit, a 3 přítomnost zkreslení (Peters et al., 2010). Psychometrické vlastnosti této škály jsou však problematické: ve faktorové analýze se ve dvou studiích jako nejlepší fit ukázal jednofaktorový model (Bastiaens et al., 2013; Peters et al., 2010), většina kognitivních zkreslení, které si dotazník klade za cíl měřit (včetně unáhlených závěrů), nekorelovala s jinými dosud používanými metodami k jejich měření (Startup, Freeman, Garety , 2017). Celkový skór z dotazníku dokáže dobře rozlišit mezi zdravými kontrolami a pacienty se schizofrenií (Bastiaens et al., 2013).

Davos Assessment of Cognitive Biases Scale (DACOBS) (van der Gaag et al., 2013) je škála měřicí tři oblasti: kognitivní zkreslení (cognitive biases), kognitivní limitace (cognitive limitations) a vyhýbavé chování (safety behaviors). Respondenti hodnotí různá tvrzení na sedmibodové Likertově škále dle míry souhlasu. Z kognitivních zkreslení zachycuje DACOBS kromě unáhlených závěrů ještě inflexibilitu přesvědčení, zvýšenou pozornost vưči hrozbě a externalizační atribuční zkreslení. Škála dokáže dobře rozlišit mezi populací s onemocněním schizofrenního okruhu a zdravými kontrolami (van der Gaag et al., 2013). Subškála unáhlených závěrů dle některých studií (van der Gaag et al., 2013) signifikantně koreluje s experimentální úlohou (beads task), dle jiných se vztahuje pouze k těžší variantě úlohy (Krężołek et al., 2019).

Př́klad položek vztahujících se k unáhleným závěrům z dotazníku DACOBS:

Nepotřebuji mnoho času k tomu, abych se rozhodl/a.

Rozhoduji se rychleji než ostatní lidé.

První myšlenka bývá většinou ta správná.

Jak je vidět z obou uvedených příkladů, přestože oba dotazníky cílí na kognitivní zkreslení, konceptualizují je odlišně. Zatímco CBQ cílí na konkrétní situace, ve kterých se 
kognitivní zkreslení mohou vyskytovat a myšlení probanda v těchto situacích, DACOBS se zaměřuje spíše na metakognitivní schopnost reflektovat, jež je vlastní docházení k závěrům.

\section{Unáhlené závěry a psychóza}

Ve vztahu ke specificitě unáhlených závěrů pro psychotická onemocnění metaanalýzy potvrzují, že unáhlené závěry jsou u pacientů z této diagnostické skupiny zastoupeny ve větší míře než u zdravých kontrol a ostatních nepsychotických onemocnění. Rozhodnutí po prezentaci 1-2 korálků pozorujeme u 48-60\% psychotických pacientů. Zdravé kontroly se takto extrémně rozhodují pouze v míře $28 \%$, průměrný počet vyžádaných informací je u nich 5-6 korálků. U ostatních psychiatrických onemocnění pozorujeme extrémní odpovědi u $38 \%$ pacientů (Dudley et al., 2016).

Unáhlené závěry lze pozorovat již u zdravých sourozenců pacientů, přičemž dle van Dael et al. (2006) jejich výkon leží mezi výkonem psychometricky definované skupiny respondentů se sklony k psychóze a výkonem pacientů. Dle některých autorů (Garety et al., 2013) tak unáhlené závěry mohou fungovat jako endofenotyp psychotických onemocnění. V rozsáhlé studii Tripoli et al. (2018) byl však vztah mezi unáhlenými závěry a skórem polygenického rizika (polygenic risk score) schizofrenie nesignifikantní. Tendence $\mathrm{k}$ unáhleným závěrům byla zaznamenána také u lidí s vysokým rizikem rozvoje psychózy, prričemž pacienti, kteř́ splňovali ultra high risk kritéria, podávali horší výsledek než respondenti, kteří naplňovali pouze kritéria bazálních symptomů (Raush et al., 2016). Unáhlené závěry byly popsány jak u prvních epizod psychotických onemocnění (Dudley et al., 2011; Falcone et al., 2015; Ormrod et al., 2012), tak u pacientů s chronickým průběhem onemocnění (Evans et al., 2015). Na rozdíl od chronických pacientů se však v časných stádiích onemocnění unáhlené závěry nejeví jako stabilní rys a při opakovaném měření zaznamenáváme změnu v pravděpodobnostním rozhodování (Dudley et al., 2013; Woodward et al., 2009). Pouze jedna studie u prvních epizod zaznamenala zlepšení v emocionální verzi testu, ale ne v klasické beads task (Menon, Mizrahi, Kapur, 2008). Naopak u pacientů s chronickým průběhem se studie shodují a nepozorují v unáhlených závěrech změnu (Andreau et al., 2018; Peters, Garety, 2006; So et al., 2012).

\section{Unáhlené závěry a bludy}

V současnosti je stále velmi diskutovaný vztah mezi aktuální př́tomností bludů a tendencí k unáhleným závěrům. Souvislost mezi bludnou ideací a tendencí k unáhleným závěrům byla pozorována již na úrovni zdravé populace u lidí, kteří dosahují vyššího skóru v dotazníku PDI (Peter's Delusion Inventory) (Ross et al., 2015). Metaanalýza Fine et al. (2007) porovnávala pacienty se schizofrenií s bludy a bez bludů, v této studii se potvrdila vyšší tendence $\mathrm{k}$ unáhleným závěrům ve skupině s bludy. Obdobné výsledky zaznamenali Dudley et al. (2016), kteř́ porovnávali skupinu pacientů (schizofrenie a porucha s bludy), aktuálně s bludy a bez bludů. Autoři nejnovější metaanalýzy (McLean, Mattiske, Balzan, 2017) se pak domnívají, že unáhlené závěry specificky souvisí s bludy, at' již u schizofrenie, nebo u ostatních psychiatrických onemocnění. Pacienti s diagnózou 
schizofrenie, kteř́ jsou aktuálně bez bludů, dosahují dle výsledků této metaanalýzy srovnatelného výkonu jako zdravé kontroly. Souvislost mezi bludy a unáhlenými závěry podporují i longitudinální studie u prvních epizod onemocnění, které společně s ústupem pozitivní symptomatologie zaznamenávají i změnu v unáhlených závěrech (Dudley et al., 2013; Menon, Mizrahi, Kapur, 2008; Woodward et al., 2009). Naproti tomu longitudinální studie na chronických pacientech opakovaně selhávají ve snaze zachytit souvislost mezi změnou v unáhlených závěrech a pozitivních symptomech (Andreau et al., 2018; Peters, Garety, 2006; So et al., 2012). Do výsledků těchto studií se může promítat více faktorů, např. hlubší kognitivní deficit, či efekt dlouholetého užívání antipsychotické medikace, v neposlední řadě také malá velikost souboru.

\section{Unáhlené závěry a kognice}

U pacientů se schizofrenií není oslabeno pouze pravděpodobnostní usuzování; kognitivní deficit, přestože značně heterogenní (Rodriguez et al., 2019), je u schizofrenie konzistentně dokumentován (Neuchterlein et al., 2004). Někteří autoři (Mahler, 2005) se proto domnívají, že unáhlené závěry jsou pouhým epifenomenem kognitivního deficitu. Ve vztahu k unáhleným závěrům bývá zkoumána především inteligence, pracovní pamět' a exekutivní funkce.

Souvislost mezi nižší inteligencí a tendencí k unáhleným závěrům byla dokumentována u zdravých sourozenců pacientů i subklinické populace (van Dael et al., 2007), u pacientů s psychotickou depresí (Corcorand, Rowse, Moore, 2008), u pacientů s perzekučními bludy (Freeman et al., 2014) a u pacientů se schizofrenií (Garety, Hemsley, Wassely, 1991; Moritz et al., 2010; Mortimer et al., 1996, Tripoli et al., 2019). Poté, co Lincoln et al. (2010) zahrnuli do analýzy i IQ, byla v jejich studii korelace mezi závažností bludů a unáhlenými závěry nesignifikantní. Ve studii Tripoli et al. (2018) byl vztah mezi unáhlenými závěry a psychózou plně mediován inteligencí, která vysvětlovala $80 \%$ unáhlených závěrů. V této studii také unáhlené závěry souvisely s polygenickým skórem inteligence. Autoři této studie se proto domnívají, že unáhlené závěry u psychóz jsou důsledkem kognitivního deficitu spíše, než by samy byly specifickým kognitivním narušením. Naproti tomu např. ve studii Garety et al (2013) nebyl vztah mezi unáhlenými závěry a IQ pozorován. Dle van Dael et al. (2007) je možné, že nižší inteligence produkuje tendenci $\mathrm{k}$ unáhleným závěrům, které pak činí daného jedince vulnerabilnějším k rozvoji psychotického onemocnění.

Ve vztahu k pracovní paměti je souvislost s vyšší tendencí k unáhleným závěrům dokumentována jak v prodromálních stádiích (Broome et al., 2007), tak u prvních epizod (Falcone et al., 2015; Ormrod et al., 2012) i u chronických pacientů (Krężołek et al., 2019; Ochoa et al., 2014; Takeda et al., 2018) a pacientů s přetrvávajícími perzekučními bludy (Freeman et al., 2014). I z tohoto důvodu se postupem času upravovaly instrukce a prezentace beads task úlohy tak, aby kladla co nejmenší nároky na pracovní pamět'. Např. probandi stále vidí, jaký je poměr mezi korálky v obou nádobách.

Studie zkoumající exekutivní funkce a unáhlené závěry také nedocházejí k jednotnému konsenzu - některé studie souvislost pozorují (Gonzáles et al., 2018; Rubio et al., 2011; Woodward et al., 2009), jiné naopak nezaznamenaly žádnou korelaci (Buck, Huddy, Lysaker, 2012). 
Andreau et al. (2015) sledovali změny v neurokognici, bludech a unáhlených závěrech u dvou skupin pacientů - jedna skupina pacientů podstoupila kognitivní remediaci, druhá metakognitivní trénink. U obou skupin došlo po skončení intervence ke změně unáhleného rozhodování, ale pouze u skupiny s metakognitivním tréninkem se také snížila závažnost bludů. Ve skupině, která podstupovala kognitivní remediaci, korelovalo zlepšení v unáhlených závěrech se zlepšením kognice, tato souvislost nebyla pozorována ve druhé skupině, ani na úrovni celého souboru pacientů, přestože kognitivní funkce se zlepšily i u pacientů z druhé skupiny.

\section{Unáhlené závěry a sociální kognice}

Výzkumů zkoumajících sociální kognici a unáhlené závěry není mnoho a jejich výsledky nejsou konzistentní. Z teoretického pohledu se přitom souvislost mezi těmito dvěma fenomény přímo nabízí - unáhlené závěry, jakožto bazální narušení procesu usuzování, mohou být podkladem pro komplexnější deficit v sociálním úsudku. V multivariační studii Woodwarda et al. (2009) však unáhlené závěry společně s exekutivními funkcemi sytily komponentu „flexibility“, zatímco teorie mysli (jedna z nejvíce zkoumaných domén sociální kognice) a verbální fluence komponentu „elaborace“. Také studie Takedy et al. (2018) nezachytila souvislost mezi teorií mysli a unáhlenými závěry.

\section{Teorie unáhlených závěrů}

V minulosti bylo formulováno několik hypotéz, proč pacienti dosahují v úloze beads task horších výsledků než zdravé kontroly.

\subsection{HYPOTÉZA LIBERÁLNÍHO PŘIJETÍ}

U pacientů s psychózou byl v různých experimentálních situacích pozorován jev, kteří autoři Moritz et al. (2007) popsali jako snížená rozhodovací hladina (lowered decision threshold). Dle Moritze et al. (2017, s. 13) se „pacienti rozhodují jako špatní statistici,

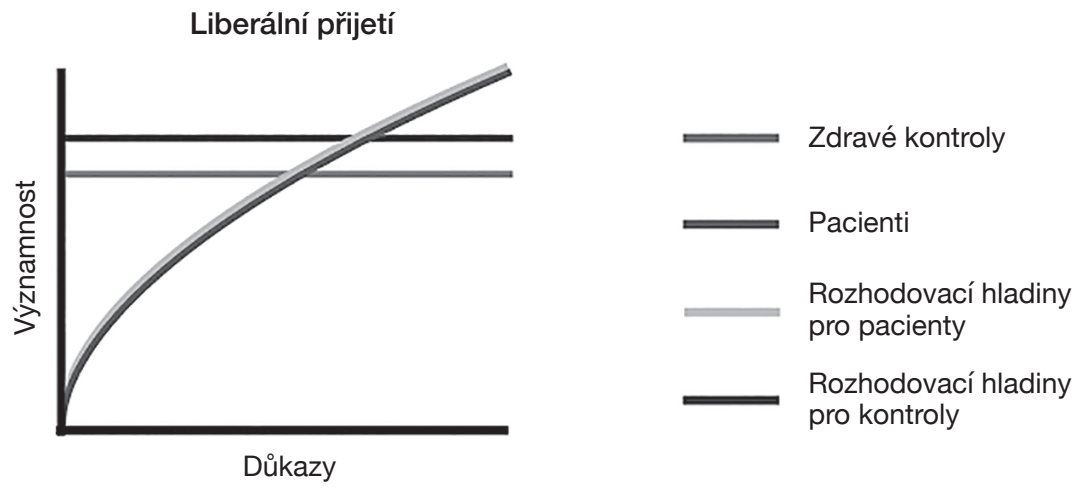

Obr. 2: Schéma zachycujicí, jakým způsobem pacienti docházejí k rozhodnutí dle Moritz et al. (2008) a teorie liberálního prijietí. Převzato a upraveno dle Sandvik (2015, s. 10) 
kteři prípisují málo podloženým jevưm význam a důležitost. “Při porovnávání subjektivní hladiny pravděpodobnosti určité situace či jevu se pacienti rozhodují na základě nižší subjektivní pravděpodobnosti než zdravé kontroly (viz Obr. 2). Liberální přijetí se např. manifestuje ve výzkumech konfirmačních zkreslení, kde mají probandi hodnotit pravděpodobnost určitých tvrzení, která jsou interpretacemi nějaké situace. Ukazuje se, že pacienti připisují vyšší pravděpodobnost i tvrzením, která zdravé kontroly považují za velmi nepravděpodobná (Moritz, Woodward, 2004). V klasické beads task úloze se tento fenomén může manifestovat tím, že pacienti již po dvou prezentovaných korálcích dosáhnou dostačující úrovně pravděpodobnosti, na které je pro ně již přijatelné se rozhodnout. Dř́vějš́i hypotéza operovala navíc s nejasností situace, kdy se předpokládalo, že čím je situace méně nejasná, tím více pacienty vybízí k unáhleným závěrům. Tuto tezi podpořila studie, ve které probandi vybírali místo ze dvou ze čtyř nádob, počet požadovaných korálků se nelišil mezi pacienty a zdravými kontrolami (Moritz, Woodward, Lambert, 2007). Jiná studie ovšem tuto hypotézu nepodpořila (Moritz et al., 2016). Liberální přijetí dle Moritze et al. (2017) pak je podkladem pro všechny pozitivní symptomy u schizofrenie, nejen bludy.

\subsection{HYPOTÉZA HYPERSALIENCE POTVRZUUÍCÍCH FAKTŮ}

Dle této hypotézy se pacienti od zdravých kontrol liší především v tom, jakou významnost připisují faktům, která potvrzují jejich hypotézu, zatímco konfliktní informace hodnotí stejně jako zdravé kontroly. Tato hypotéza předpokládá, že pacienti i zdravé kontroly se rozhodují na stejné rozhodovací hladině, ale liší se v tom, jakou významnost přikládají faktům, které potvrzují jejich hypotézu. Pro pacienty jsou fakta, která jsou v souladu s jejich hypotézou, významnější než pro zdravé kontroly, proto požadované optimální rozhodovací hladiny dosáhnou dř́ve (viz Obr. 3) (Speechley, Whitman, Woodward, 2010).

Tato hypotéza navazuje na Kapurovu (2003) teorii aberantní salience, která poukazuje na vliv hyperaktivního dopaminového systému (v oblasti striata a mezimozku) na prípisování salience nepodstatným podnětům. U pacientů se schizofrenií se spekuluje o tom, že vlivem dopaminové nerovnováhy připisují nadměrnou významnost jevům a podnětům, které jsou v daném kontextu irelevantní a podceňují ty důležité. Přestože výzkumy naznačují souvislost mezi atribucí salience a závažností bludů u high-risk populace (Rosier

Hypersalience faktů

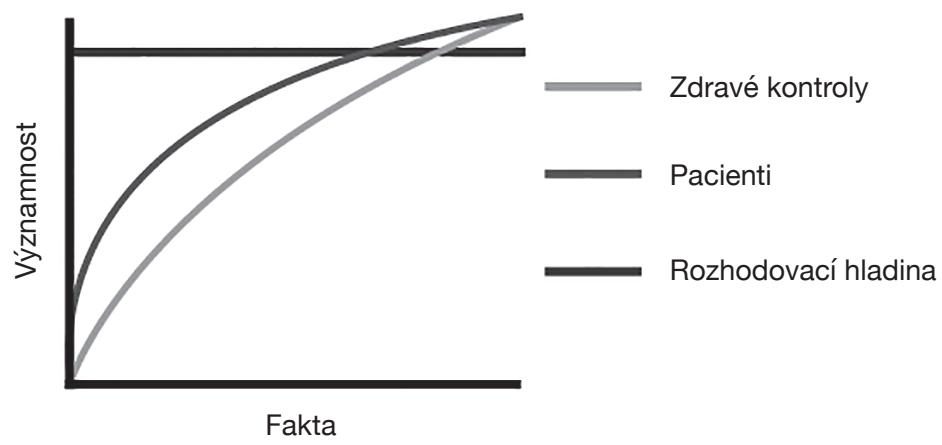

Obr. 3: Schéma zachycujicí, jak pacienti a kontroly docházi k rozhodnutí, dle Speechley Whitman, Woodward (2010). Převzato a upraveno dle Sandvik (2015, s. 10). 
et al., 2013), studie sledující efekt podání agonistů dopaminu (L-dopa, metamfetamin) (Andreau at al., 2013; Ermakova et al., 2014) a haloperidolu (dopaminový antagonista) na unáhlené závěry nepozorují u zdravých kontrol žádný efekt.

\subsection{POTŘEBA KOGNITIVNÍHO UZAVŘENÍ}

Potřeba kognitivního uzavření je fenomén na pomezí kognitivního zkreslení a osobnostního rysu. Lidé s vysokou potřebou kognitivního uzavření jsou poháněni touhou získat odpověd' na nevyjasněné otázky, namísto setrvání v nepř́ijemném stavu nejistoty (Kruglanski, 1989). Výsledky dosavadních výzkumů však souvislost unáhlených závěrů a potřeby kognitivního uzavření spíše nepodporují (Colbert, Peters, 2002; McKay et al, 2007; Zawadski et al., 2012).

\section{Možnosti terapeutického ovlivnění unáhlených závěrů pomocí (meta)kognitivního tréninku}

\subsection{METAKOGNITIVNÍ TRÉNINK PRO PSYCHÓZY}

Metakognitivní trénink pro psychózy (MTC) (Moritz, Woodward, 2007) je metoda, která se snaží skrze ovlivnění nejčastěji pozorovaných kognitivních zkreslení a sociálně-kognitivních deficitů snížit pozitivní symptomatologii u pacientů s psychózami. MTC kombinuje prvky CRT (cognitive remediation therapy), CBTp (kognitivně-behaviorální terapie pro psychózy) a psychoedukaci. MTC je rozděleno na osm modulů, které jsou zaměřené na trénování některého z kognitivních zkreslení. Konkrétně jsou cvičení zaměřena na atribuce, unáhlené závěry, změnu přesvědčení, rozpoznávání emocí, metapamět' (schopnost vyhodnotit kapacitu a funkce vlastní paměti), teorii mysli, náladu a self-esteem (Moritz et al., 2010). Tréninkové moduly existují jak ve skupinové, tak individualizované formě a jsou přeloženy i do českého jazyka (dostupné zdarma na následující adrese: https://clinical-neuropsychology.de/mct-psychosis-manual-czech/). Dle Moritze et al. (2014) se MTC snaží v pacientech „zasadit zrnko pochybností“ skrze poukazování na nedokonalost lidské kognice. Pacienti jsou postupně seznamováni s nejčastějšími zkresleními, která jsou reportována u psychóz. Zkreslení jsou nejprve demonstrována na každodenních situacích a normalizována skrze to, že takto se mohou vyskytovat v podstatě u každého, zároveň se klade důraz na to, aby pacienti pochopili, že tato zkreslení bývají u psychotických onemocnění zvýrazněná. Pacienti si postupně zvědomují chyby v usuzování, kterých se mohou dopouštět, a zároveň se učí neukvapovat se a zpochybňovat svá vlastní přesvědčení. Většina studií kromě jedné (Van Oosterhout et al. 2014) pozorovala u pacientů zlepšení v závažnosti bludů po absolvování tréninku (Andreau et al., 2015; Aghotor et al, 2010; Balzan et al., 2014; Balzan et al., 2019; Briki et al., 2014; Erawati et al., 2014; Favrod et al., 2014; Gaweda et al., 2015; Kumar et al., 2010; Kuokkanen et al., 2014; Moritz et al., 2013; Moritz et al., 2011), malý až středně velký efekt zjistily i dvě metaanalýzy (Eicher, Berna, 2016; Liu et al., 2018). Naproti tomu metaanalýza (Van Oosterhout et al. 2014), která analyzovala pečlivě vybrané randomizované kontrolované studie, reportuje pouze nesignifikantní malé velikosti efektu jak na pozitivní symptomy či bludy, tak na unáhlené závěry. Ve vztahu ke snížení unáhlených závěrů jsou výsledky studií smiŕ̌ené, některé studie zaznamenaly po absolvování tréninku menší tendenci k ukvapeným závěrům (Andreau et al., 2015; Aghotor et al., 2010; Balzan et al., 2014; Moritz et al., 2011; Ochoa et al., 
2017; Ross et al., 2011;), v jiných naopak nebyla pozorována žádná změna (Gaweda et al., 2015; Kuokkanen et al., 2014, Moritz et al., 2011; Van Oosterhout et al. 2014). Individualizovaná forma tréninku vykazuje vyšší efekt než skupinový trénink (Liu et al., 2018).

\subsection{TRÉNINK SOCIÁLNÍ KOGNICE A INTERAKCE}

Kromě metakognitivního tréninku, který je v současnosti pravděpodobně nejvíce zacílenou intervencí na snižování kognitivních biasů pracuje s remediací unáhlených závěrů i Trénink sociální kognice a interakce (SCIT). V porovnání s MCT je tato metoda více zaměřená na oblast sociální kognice (rozpoznávání emocí a teorie myslí) a na atribuční styl než na kognitivní zkreslení obecně, velmi často se ale během sezení pracuje právě $\mathrm{s}$ tendencí $\mathrm{k}$ unáhleným závěrům. Na různých př́kladech z každodenního sociálního života se pacienti učí, jak se vyhnout ukvapenému usuzování. V ideálním případě se pracuje ve skupině, program využívá kromě poměrně běžných materiálů (jako jsou pracovní listy a prezentaci) i tréninkové videoukázky (Roberts, Penn, Combs, 2016). Studie, sledující efekt SCIT, se zaměřují především na oblast sociálního fungování a sociální kognice. Pokud je autorům známo, do současnosti nebyla provedena studie, která by př́mo zkoumala efekt tohoto programu na snížení unáhlených závěrů.

\section{Diskuze}

Tato přehledová studie shrnuje aktuální stav poznání v oblasti unáhlených závěrů u psychotických onemocnění. Koncept unáhlených závěrů přinesl nový směr ve výzkumu bludů u schizofrenie a stočil pozornost na obecnou schopnost pacientů docházet $\mathrm{k}$ úsudkům. Zatímco výzkumů na unáhlené závěry každým rokem přibývá, problémy spojené především s metodologickými otázkami stále přetrvávají a nedostává se jim patřičné pozornosti výzkumných týmů.

Problematická je především samotná úloha beads task. Do budoucna by výzkum v této oblasti velmi benefitoval z vytvoření úlohy, která bude měřit stejný fenomén, ale bude pro pacienty více srozumitelná. Určitou naději v tomto směru skýtá úloha box task, poslední studie však nenašla korelaci s beads task, otázkou tak zůstává, zda obě úlohy měří stejný koncept. Pro další výzkumy by vzhledem k nárokům na kognitivní funkce mělo být bazální kontrolovat IQ a neurokognici (minimálně pracovní pamět’ a exekutivní funkce).

I vzhledem k metodologickým problémům zůstává stále otevřená otázka vztahu unáhlených závěrů a bludů, potažmo pozitivní symptomatologie. Přestože metaanalýzy potvrzují souvislost bludů a unáhlených závěrů, výsledky longitudinálních studií se rozcházejí v tom, zda se v čase se závažností bludů snižuje i tendence k unáhleným závěrům. Dle Andreau et al. (2018) lze výsledky metaanalýz interpretovat spíše jako rozdíly mezi př́itomností vulnerability k rozvoji bludů. Garety a Freeman (2013) se domnívají, že unáhlené závěry se jeví zároveň jako trait marker bludů, který zvyšuje riziko propuknutí bludné produkce, tak state markerem, který je př́značný pro akutní fáze. Podobně se jako o psychologickém fenoménu fungujícím jako trait i state marker uvažuje např. o vztahu teorie mysli a pozitivních symptomů (van Dael, 2007). Pro zodpovězení této otázky je však zapotřebí dalších longitudinálních studií s dostatečně velkým výzkumným vzorkem a kvalitní metodologií. Budoucí výzkumy by se také neměly izolovat pouze na sledování unáhlených závěrů a kognice, ale zahrnout i sociální kognici a metakognici. 
Za důležitý však považujeme především léčebný potenciál remediačních programů, které se orientují na práci s kognitivními zkresleními. Vzhledem k tomu, že farmakologické intervence v mnoha př́padech pouze sníží floridnost pozitivních symptomů, zatímco jejich jádrová složka zůstává nezpochybnitelná, otevírá se prostor pro terapeutickou a psychoedukační práci. Právě tréninkové programy, které vedou k rozvoji metakognitivních a sociálně-kognitivních schopností, představují nadějnou cestu, jak pacienty učit přemýšlet o vlastních přesvědčeních jiným způsobem, než jaký možná používají automaticky. Ohledně efektivity metakognitivního tréninku dosud nepanuje jednoznačná shoda. Přestože většina studií podporuje efekt tréninku na snížení závažnosti bludů, výsledky metaanalýz se rozcházejí v závislosti na zvolených kritériích pro zahrnutí studie do analýzy. Stejně tak se rozcházejí výsledky jednotlivých výzkumů ohledně zlepšení tendence k unáhleným závěrům po absolvování programu, což jen odráží rozpolcenost, která panuje v názorech na stabilitu a proměnlivost unáhlených závěrů v čase. V oblasti sledování efektivity tréninku metakognitivních funkcí by výzkum benefitoval především z kvalitních studií s dostatečným počtem respondentů a kontrolní skupinou s rozdílnou intervencí.

\section{Závěr}

V tomto článku jsme představily koncept unáhlených závěrů, současné poznatky z jeho výzkumu u psychotických onemocnění a možnosti jeho ovlivnění pomocí různých intervencí. Unáhlené závěry se u psychotických onemocnění vyskytují ve větší míře než u zdravých kontrol a ostatních psychiatrických onemocnění, část studií přináší podporu pro souvislost unáhlených závěrů s bludy. Výrazný problém ve výzkumu unáhlených závěrů však představují samotné experimentální úlohy, u kterých je často zpochybňováno, zda jsou pro pacienty srozumitelné. Pro budoucí výzkumy tak bude největší výzvu představovat vytvoření validní metodologie $\mathrm{k}$ měření unáhlených závěrů a iniciace longitudinálních studií, které by mohly více ozřejmit jejich souvislost s bludy. Za nejdůležitější však považujeme nadějné výsledky z programů na trénink metakognice, které naznačují, že s unáhlenými závěry je možno terapeuticky pracovat. Jsou však potřeba další studie s kontrolní skupinou a placebo intervencí, které by podpořily efektivitu programu a pomohly rozklíčovat, zda tyto intervence mohou pomoci i ke stabilizaci pozitivních psychotických symptomů, jako jsou např́klad bludy.

Tato studie je výsledkem badatelské činnosti podporované projektem číslo LO1611 za finanční podpory MŠMT v rámci programu NPU a projektem PharmaBrain, č. CZ.02.1.0 1/0.0/0.0/16_025/0007444 v rámci OP VAV.

\section{LITERATURA}

Adams, R. A., Stephan, K. E., Brown, H. R., Frith, C. D., \& Friston, K. J. (2013). The computational anatomy of psychosis. Frontiers in Psychiatry, 4(47), 1-26. https://doi.org/10.3389/fpsyt.2013.00047

Aghotor, J., Pfueller, U., Moritz, S., Weisbrod, M., \& Roesch-Ely, D. (2010). Metacognitive training for patients with schizophrenia (MCT): Feasibility and preliminary evidence for its efficacy. Journal of Behavior Therapy and Experimental Psychiatry, 41, 207-211. https://doi.org/10.1016/j.jbtep.2010.01.004 
Andreou, C., Moritz, S., Veith, K., Veckenstedt, R., \& Naber, D. (2013). Dopaminergic modulation of probabilistic reasoning and overconfidence in errors: A double-blind study. Schizophrenia Bulletin, 40(3), 558-565. https://doi.org/10.1093/schbul/sbt064

Andreou, C., Schneider, B. C., Balzan, R. P., Roesch-Ely, D., \& Moritz, S. (2015). Neurocognitive deficits are relevant for the jumping-to-conclusions bias, but not for delusions: A longitudinal study. Schizophrenia Research: Cognition, 2, 8-11. https://doi.org/10.1016/j.scog.2015.02.001

Andreau, C., Veckenstedt, R., Lüdke, T., Bozikas, V., P., \& Moritz, S. (2018). Differential relationship of jumping-to-conclusions and incorigibility with delusion severity. Psychiatry Research, 264, 297-301. https://doi. org/10.1016/j.psychres.2018.04.014

Balzan, R. P., Ephraums R., Delfabbro, P., \& Andreau, C. (2017) Beads task vs. box task: The specifity of the jumping to conclusions bias. Journal of Behavior Therapy and Experimental Psychiatry, 56, 42-50. https:// doi.org/10.1016/j.jbtep.2016.07.017

Balzan, R. P., Delfabbro, P., \& Galletly, C. (2012). Delusion-proneness or miscomprehension? A re-examination of the jumping-to-conclusions bias. Australian Journal Of Psychology, 64(2), 100-107. https://doi.org $/ 10.1177 / 0004867411435291$

Balzan, R. P., Delfabbro, P. H., Galletly, C. A., \& Woodward, T. S. (2014). Metacognitive training for patients with schizophrenia: preliminary evidence for a targeted, single-module programme. Australian \& New Zealand Journal of Psychiatry, 48(12), 1126-1136. https://doi.org/10.1177/0004867413508451

Balzan, R. P., Mattiske, J. K., Delfabbro, P., Liu, D., \& Galletly, C. (2019). Individualized Metacognitive Training $(\mathrm{MCT}+)$ Reduces Delusional Symptoms in Psychosis: A Randomized Clinical Trial. Schizophrenia Bulletin, 45(1), 27-36. https://doi.org/10.1093/schbul/sby 152

Bastiaens, T., Claes, L., Smits, D., De Wachter, D., van der Gaag, M., \& De Hert, M. (2013). The Cognitive Biases Questionnaire for Psychosis (CBQ-P) and the Davos Assessment of Cognitive Biases (DACOBS): validation in a Flemish sample of psychotic patients and healthy controls. Schizophrenia research, 147(2-3), 310-314. https://doi.org/10.1016/j.schres.2013.04.037

Blackburn, I. M., Jones, S., \& Lewin, R. J. P. (1986). Cognitive style in depression. British Journal of Clinical Psychology, 25, 241-251. https://doi.org/10.1111/j.2044-8260.1986.tb00704.x

Brennan, J. H. \& Hemsley, D. R. (1984). Illusory correlations in paranoid and nonparanoid schizophrenia. British Journal of Clinical Psychology, 23, 225-226. https://doi.org/10.1111/j.2044-8260.1984.tb00649.x

Briki, M., Monnin, J., Haffen, E., Sechter, D., Favrod, J., Netillard, C., ... \& Bonin, B. (2014). Metacognitive training for schizophrenia: a multicentre randomised controlled trial. Schizophrenia research, 157(1-3), 99-106. https://doi.org/10.1016/j.schres.2014.06.005

Broome, M. R., Johns, L. C., Valli, I., Woolley, J. B., Tabraham, P., Brett, C., ... McGuire, P. K. (2007). Delusion formation and reasoning biases in those at clinical high risk for psychosis. British Journal of Psychiatry, 191(51), 38-42. https://doi.org/10.1192/bjp.191.51.s38

Bryod, A., Balzan, R. P., Woodward, T. S., \& Allen, P. (2017). Dopamine, cognitive biases and assessment of certainty: A neurocognitive model od delusions. Clinical Psychology Review, 54, 96-106. https://doi.org /10.1016/j.cpr.2017.04.006

Buck, K.D.,Warman, D.M.,Huddy, V., \& Lysaker, P. H., (2012). The relationship of metacognition with jumping to conclusions among persons with schizophrenia spectrum disorders. Psychopathology, 45(5), 271-275. https://doi.org/10.1159/000330892

Colbert, S. M., \& Peters, E. R. (2002). Need for closure and jumping-to-conclusions in delusion-prone individuals. Journal of Nervous Mental Disorders, 190, 27-31. https://doi.org/10.1097/00005053-200201000-00007

Corcoran R, Rowse G, \& Moore R. (2008) A transdiagnostic investigation of 'theory of mind' and 'jumping toconclusions' in patients with persecutory delusions. Psychological Medicine, 38, 1577-1583. https://doi .org/10.1017/S0033291707002152

Dudley, R, Daley, K., Nicolson, M., Shaftoe, D., Spencer, H., Cavanagh, K., \& Freeston, M. (2013). „Jumping to conclusions in first psychosis": A longitudinal study. British Journal of Clinical Psychology, 52, 380-393. https://doi.org/10.1111/bjc. 12023

Dudley, R., Shaftoe, D., Cavanagh, K., Spencer, H., Ormrod, J., Turkington, D., \& Freenston, M. (2011) Jumping to conclusions in frst-episode psychosis. Early Intervention in Psychiatry, 5, 50-56. https://doi.org /10.1111/j.1751-7893.2010.00258.x

Dudley, R., Taylor, P., Wickham, S., \& Hutton, P. (2016). Psychosis, Delusions and the „Jumping to Conclusions“ Reasoning Bias: A Systematic Review and Meta-analysis. Schizophrenia Bulletin, 42(3), 652-665. https://doi.org/10.1093/schbul/sbv150 
Eichner, C., \& Berna, F. (2016). Acceptance and efficacy of metacognitive training (MCT) on positive symptoms and delusions in patients with schizophrenia: a meta-analysis taking into account important moderators. Schizophrenia Bulletin, 42(4), 952-962. https://doi.org/10.1093/schbul/sbv225

Erawati, E., Keliat, B. A., Helena, N., \& Hamid, A. (2014). The influence of metacognitive training on delusion severity and metacognitive ability in schizophrenia. Journal of psychiatric and mental health nursing, 21(9), 841-847. https://doi.org/10.1111/jpm.12130

Ermakova, A. O., Ramachandra, P., Corlett, P. R., Fletcher, P. C., \& Murray, G. K. (2014). Effects of methamphetamine administration on information gathering duringprobabilistic reasoning in healthy humans. PLoS One, 9(7), e102683. https://doi.org/10.1371/journal.pone.0102683

Evans, S. L., Averbeck, B. B., \& Furl, N. (2015) Jumping to conclusions in schizophrenia. Neuropsychiatrich Disease and Treatment, 11, 1615-1624. https://doi.org/10.2147/NDT.S56870

Falcone, M. A., Murray, R. M., Wiffen, B. D., O’Connor, J. A., Russo, M., Kolliakou, A., ... Jolley, S. (2015). Jumping to conclusions, neuropsychological functioning, and delusional beliefs in first episode psychosis. Schizophrenia Bulletin, 41(2), 411-418. https://oi.org/10.1093/schbul/sbu104

Favrod, J., Rexhaj, S., Bardy, S., Ferrari, P., Hayoz, C., Moritz, S., .. \& Bonsack, C. (2014). Sustained antipsychotic effect of metacognitive training in psychosis: a randomized-controlled study. European Psychiatry, 29(5), 275-281. https://doi.org/10.1016/j.eurpsy.2013.08.003

Fine, C., Gardner, M., Craigie, J., \& Gold, I. (2007). Hopping, skipping or jumping to conclusions? Clarifying the role of the JTC bias in delusions. Cognitive Neuropsychiatry, 12, 46-77. https://doi.org/10 $.1080 / 13546800600750597$

Freeman, D., Startup, H., Dunn, G., Černis, E., Wingham, G., Pugh, K., .. \& Kingdon, D. (2014). Understanding jumping to conclusions in patients with persecutory delusions: working memory and intolerance of uncertainty. Psychological medicine, 44(14), 3017-3024. https://doi.org/10.1017/S0033291714000592

Friston, K. (2005). A theory of cortical responses. Philosophical Translations of Royal Society London B. Biological Science. 36(1456). 815-836. https://doi.org/10.1098/rstb.2005.1622

Garety, P. A., \& Freeman, D. (2013). The past and future of delusions research: From the inexplicable to the treatable. British Journal of Psychiatry, 203(5), 327-333. https://doi.org/10.1192/bjp.bp.113.126953

Garety, P. A., Hemsley, D. R., \& Wessely, S. (1991). Reasoning in deluded schizophrenic and paranoid patients. Biases in performance on a probabilistic inference task. Journal of Nervous and Mental Disease, 179(4), 194-201. https://doi.org/10.1097/00005053-199104000-00003

Garety, P., Joyce, E., Jolley, S., Emsley, R., Waller, H., Kuipers, E., Freeman, D. (2013). Neuropsychological functioning and jumping to conclusions in delusions. Schizophrenia Research, 150(2-3), 570-574. https:// doi.org/10.1016/j.schres.2013.08.035

Gawęda, Ł., Krężołek, M., Olbryś, J., Turska, A., \& Kokoszka, A. (2015). Decreasing self-reported cognitive biases and increasing clinical insight through meta-cognitive training in patients with chronic schizophrenia. Journal of behavior therapy and experimental psychiatry, 48, 98-104. https://doi.org/10.1016/j.jbtep .2015 .02 .002

González, L. E., López-Carrilero, R., Barrigón, M. L., Grasa, E., Barajas, A., Pousa, E., ... \& Pélaez, T. (2018). Neuropsychological functioning and jumping to conclusions in recent onset psychosis patients. Schizophrenia research, 195, 366-371. https://doi.org/10.1016/j.schres.2017.09.039

Huq, S. F., Garety, P.A., Hemsley, D. R. (1988) Probabilistic judgements in deluded and non-deluded subjects. The Quarterly Journal of Experimental Psychology Section A, 40(4), 801-812. https://doi.org $/ 10.1080 / 14640748808402300$

Chu, H., Sun, X., \& So, S. (2015). The Beads, the Fish and the Box: Interrelationship between "jumping to conclusions" tasks and their links with cognitive abilities (Abstracts of the 23rd European Congress of Psychiatry). European Psychiatry, 30, 1706. https://doi.org/10.1016/S0924-9338(15)31309-2

Irwin, H. J., Drinkwater, K., \& Dagnall, N. (2014). Are believers in the paranormal inclined to jump to conclusions?. Australian Journal of Parapsychology, 14(1), 69.

Krężołek, M., Pionke, R., Banaszak, B., Kokoszka, A., \& Gawęda, Ł. (2019). The relationship between jumping to conclusions and neuropsychological functioning in schizophrenia. Psychiatry research, 273, 443-449. https://doi.org/10.1016/j.psychres.2019.01.035

Kapur, S. (2003). Psychosis as a state of aberrant salience: A framework linking biology, phenomenology, and pharmacology in schizophrenia. American Journal of Psychiatry, 160(1), 13-23. https://doi.org/10.1176 /appi.ajp.160.1.13 
Kruglanski, A. W. (1989). Lay Epistemics and Human Knowledge: Cognitive and Motivational Bases. New York: Plenum.

Kumar, D., Zia Ul Haq, M., Dubey, I., Dotiwala, K., Siddiqui, S. V., \& Abhishek, P. (2010). Effect of meta-cognitive training in the reduction of positive symptoms in schizophrenia. European Journal of Psychotherapy \& Counselling, 12, 149-158. https://doi.org/10.1080/13642537.2010.488875

Kuokkanen, R., Lappalainen, R., Repo-Tiihonen, E., \& Tiihonen, J. (2014). Metacognitive group training for forensic and dangerous non-forensic patients with schizophrenia: A randomised controlled feasibility trial. Criminal Behaviour and Mental Health, 24(5), 345-357. https://doi.org/10.1002/cbm.1905

Lim, M. H., Gleeson, J. F., \& Jackson, H. J. (2012). The jumping-to-conclusions bias in new religious movements. The Journal of nervous and mental disease, 200(10), 868-875. https://doi.org/10.1097/NMD $.0 \mathrm{~b} 013 \mathrm{e} 31826 \mathrm{~b} 6 \mathrm{eb} 4$

Lincoln, T. M., Ziegler, M., Mehl, S., \& Rief, W. (2010). The jumping to conclusions bias in delusions: Specificity and changeability. Journal of Abnormal Psychology, 119, 40-49. https://doi.org/10.1037/a0018118

Liu, Y. C., Tang, C. C., Hung, T. T., Tsai, P. C., \& Lin, M. F. (2018). The Efficacy of metacognitive Training for Delusions in Patients With Schizophrenia: A Meta-Analysis of Randomized Controlled Trials Informs Evidence-Based Practice. Worldviews on Evidence-Based Nursing, 15(2), 130-139. https://doi.org/10.1111 /wvn. 12282

Maher, B. A. (1974). Delusional thinking and perceptual disorder. Journal of Individual Psychology, 30, 98-113.

Maher, B. (2005). Delusional thinking and cognitive disorder. Integrative Physiological \& Behavioural Science, 40(3), 136-146. https://doi.org/10.1007/BF03159710

McKay, R., Langdon, R., \& Coltheart, M. (2006). Need for closure, jumping to conclusions, and decisiveness in delusion-prone individuals. The Journal of Nervous and Mental Disease, 194, 422-426.https://doi .org/10.1097/01.nmd.0000221353.44132.25

McLean, B. F., Mattiske, J. K., \& Balzan, R. P. (2017). Association of the jumping to conclusions and evidence integration biases with delusions in psychosis: A detailed meta-analytic approach. Schizophrenia Bulletin, 43(2), 344-354. https://doi.org/10.1093/schbul/sbw056

Menon, M., Mizrahi, R., \& Kapur, S. (2008). 'Jumping to conclusions' and delusions in psychosis: relationship and response to treatment. Schizophrenia Research, 98 (1-3), 225-231. https://doi.org/10.1016/j.schres .2007 .08 .021

Moritz, S., Andreou, C., Schneider, B. C., Wittekind, C. E., Menon, M., Balzan, R. P. \& Woodward, T. S. (2014). Sowing the seeds of doubt: A narrative review on metacognitive training in schizophrenia. Clinical Psychology Review, 34, 358-366. https://doi.org/10.1016/j.cpr.2014.04.004

Moritz, S., Göritz, A. S., Balzan, R. P., Gawęda, Ł., Kulagin, S. C., \& Andreou, C. (2017). A new paradigm to measure probabilistic reasoning and a possible answer to the question why psychosis-prone individuals jump to conclusions. Journal of Abnormal Psychology, 126(4), 406-415. https://doi.org/10.1037/abn0000262

Moritz, S., Kerstan, A., Veckenstedt, R., Randjbar, S., Vitzthum, F., Schmidt, C., et al. (2011). Further evidence for the efficacy of a metacognitive group training in schizophrenia. Behaviour Research and Therapy, 49, 151-157. https://doi.org/10.1016/j.brat.2010.11.010

Moritz, S., Pfuhl, G., Lüdtke, T., Menon, M., Balzan, R. P., \& Andreau, Ch. (2017) Two stage cognitive theory of the positive symptoms of psychosis.Highlighting the role of lowered decision tresholds. Journal of Behavioral Therapy \& Experimental Psychiatry, 56, 12-20. https://doi.org/10.1016/j.jbtep.2016.07.004

Moritz, S., Scheu, F., Andreou, C., Pfueller, U., Weisbrod, M., Roesch-Ely, D. (2016) Reasoning in psychosis: risky but not necessarily hasty. Cognitive Neuropsychiatry, 21(2), 91-106. https://doi.org/10.1080/135468 05.2015 .1136611

Moritz, S., Veckenstedt, R., Bohn, F., Hottenrott, B., Scheu, F., Randjbar, S., et al. (2013). Complementary group Metacognitive Training (MCT) reduces delusional ideation in schizophrenia. Schizophrenia Research, 151, 61-69. https://doi.org/10.1016/j.schres.2013.10.007

Moritz, S., Veckenstedt, R., Hottenrott, B., Woodward, T.S., Randjbar, S., \& Lincoln, T.M., (2010). Different sides of the same coin? Intercorrelations of cognitive biases in schizophrenia. Cognitive Neuropsychiatry, 15, 406-421. https://doi.org/10.1080/13546800903399993

Moritz, S., Veckenstedt, R., Randjbar, S., Vitzthum, F., \& Woodward, T. S. (2011). Antipsychotic treatment beyond antipsychotics: Metacognitive intervention for schizophrenia patients improves delusional symptoms. Psychological Medicine, 41, 1823-1832. https://doi.org/10.1017/S0033291710002618

Moritz, S., Vitzthum, F., Randjbar, S., Veckenstedt, R. \& Woodward, T. S. (2010). Detecting and defusing 
cognitive traps: Metacognitive intervention in schizophrenia. Current Opinion in Psychiatry, 23, 561-569. https://doi.org/10.1097/YCO.0b013e32833d16a8

Moritz, S., \& Woodward, T. (2004). Plausibility judgment in schizophrenic patients: Evidence for a liberal acceptance bias. German Journal of Psychiatry, 7, 66-74.

Moritz, S., \& Woodward, T. S. (2005). Jumping to conclusions in delusional and non-delusional schizophrenic patients. British Journal of Clinical Psychology, 44, 193-207. https://doi.org/10.1348/014466505X35678

Moritz, S., \& Woodward, T. S. (2007). Metacognitive training in schizophrenia: from basic research to knowledge translation and intervention. Current Opinion in Psychiatry, 20(6), 619-625. https://doi.org /10.1097/YCO.0b013e3282f0b8ed

Moritz, S., Woodward, T. S., \& Lambert, M. (2007). Under what circumstances do patients with schizophrenia jump to conclusions? A liberal acceptance account. British Journal of Clinical Psychology, 46(2), 127-137. https://doi.org/10.1348/014466506X129862

Mortimer, A. M., Bentham, P., McKay, A. P., Quemanda, I., Clare, L., \& Eastwood, N. (1996). Delusions in schizophrenia: A phenomenological and psychological exploration. Cognitive Neuropsychiatry, 1, 289-304. https://doi.org/10.1080/135468096396451

Nuechterlein, K. H., Barch, D. M., Gold, J., M., Goldberg, T.E., Green, M.F., \&Heaton, R.K. (2004) Identification od separable cognitive factors in schizophrenia. Schizophrenia Research, 72, 29-39. https://doi. org/10.1016/j.schres.2004.09.007

Ochoa, S., Haro, J. M., Huerta-Ramos, E., Cuavas-Esteban, J., Stephan-Otto, C., Usall, J., Nieto, L., \& Brebion, G. (2014) Relation between jumping to conclusion and cognitive functioning in people with schizophrenia in contrast with healthy participants. Schizophrenia Research, 159, 211-217. https://doi.org/10.1016 j.schres.2014.07.026

Ochoa, S., López-Carrilero, R., Barrigón, M. L., Pousa, E., Barajas, A., Lorente-Rovira, E., ... \& Birulés, I. (2017). Randomized control trial to assess the efficacy of metacognitive training compared with a psycho-educational group in people with a recent-onset psychosis. Psychological medicine, 47(9), 1573-1584. https:// doi.org/10.1017/S0033291716003421

Ormrod, J., Shaftoe, D., \& Cavanagh, K. (2012) A pilot study exploring the contribution of working memory to "jumping to conclusions" in people with frst episode psychosis. Cognitive Neuropsychiatry, 17,97-114. https://doi.org/10.1080/13546805.2011.569372

Peters, E., \& Garety, P. (2006). Cognitive functioning in delusions: A longitudinal analysis. Behaviour Research and Therapy, 44, 481-514. https://doi.org/10.1016/j.brat.2005.03.008

Peters, E., Moritz, S., Wiseman, Z., Greenwood, K., Kuipers, E., Schwannauer, M., ... Garety, P. (2010). The cognitive biases questionnaire for psychosis (CBQP). Schizophrenia Research, 117(2-3), 413-413. https:// doi.org/10.1093/schbul/sbs199

Phillips, L. D. \& Edwards, W. (1966). Conservatism in a simple probabilistic inference task. Journal of Experimenial Psychology, 72, 346-354. https://doi.org/10.1037/h0023653

Rausch, F., Eisenacher, S., Elkin, H., Englisch, S., Kayser, S., Striepens, N., et al. (2016). Evaluation of the 'Jumping to conclusions' bias in different subgroups of the at-risk mental state: from cognitive basic symptoms to UHR criteria. Psychological Medicine, 46, 2071-2081. https://doi.org/10.1017/S0033291716000465

Rodriguez, M., Zaytseva, Y., Cvrčková, A., Dvořaček, B., Dorazilová, A., Jonáš, J., ... \& Španiel, F. (2019). Cognitive Profiles and Functional Connectivity in First-Episode Schizophrenia Spectrum Disorders-Linking Behavioral and Neuronal Data. Frontiers in psychology, 10. https://doi.org/10.3389/fpsyg.2019.00689

Roberts, D. L., Penn, D. L., \& Combs, D. R. (2016). Social cognition and interaction training (SCIT): Group psychotherapy for schizophrenia and other psychotic disorders, clinician guide. Oxford University Press.

Roiser, J. P., Howes, O. D., Chaddock, C. A., Joyce, E. M., \& McGuire, P. (2013). Neuraland behavioral correlates of aberrant salience in individuals at risk for psychosis. Schizophrenia Bulletin, 39(6), 1328-1336. https:// doi.org/10.1093/schbul/sbs147

Ross, K., Freeman, D., Dunn, G., \& Garety, P. (2011). A randomized experimental investigation of reasoning training for people with delusions. Schizophrenia Bulletin, 37, 324-333. https://doi.org/10.1093/schbul $/ \operatorname{sbn} 165$

Ross, R. M., McKay, R., Coltheart, M., \& Langdon, R. (2015). Jumping to conclusions about the beads task? A meta-analysis of delusional ideation and data-gathering. Schizophrenia Bulletin, 41(5), 1183-1191. https:// doi.org/10.1093/schbul/sbu187 
Rubio, J. L., Ruiz-Veguilla, M., Hernández, L., Barrigón, M.L., Salcedo, M.D., Moreno, J.M., Gómez, E.,Moritz, S., \& Ferrín, M. (2011). Jumping to conclusions in psychosis: a faulty appraisal. Schizophrenia Research, 133 (1-3), 199-204. https://doi.org/10.1016/j.schres.2011.08.008

Sandvik, K. (2015). Decision-making in schizophrenia. (Master thesis). Norwegian University of Science and Technology, Trondheim.

So, S. H., Freeman, D., Dunn, G., Kapur, S., Kuipers, E., Bebbington, P., Fowler, D., Garety, P.A. (2012). Jumping to conclusions, a lack of belief flexibility and delusional conviction in psychosis: a longitudinal investigation of the structure, frequency, andrelatedness of reasoning biases. Journal of Abnormal Psychology, 121, 129-139. https://doi.org/ 10.1037/a0025297

Speechley, W. J., Whitman, J. C., \& Woodward, T. S. (2010). The contribution of hypersalience to the ,jumping to conclusions“ bias associated with delusions in schizophrenia. Journal of Psychiatry \& Neuroscience, 35(1), 7-17. https://doi.org/10.1503/jpn.090025

Startup, H., Freeman, D., Garety, P. A. (2007). Persecutory delusions and catastrophic worry in psychosis: developing the understanding of delusion distress and persistence. Behavior Research and Therapy. 45(3), 523-537. https://doi.org/10.1016/j.brat.2006.04.006

Takeda, T., Nakataki, M., Ohta, M., Hamatani, S., Matsuura, K., \& Ohmori, T. (2018). Effect of cognitive function on jumping to conclusion in patients with schizophrenia. Schizophrenia research. Cognition, 12, 50-55. https://doi.org/10.1016/j.scog.2018.04.002

Tripoli, G., Quattrone, D., Ferraro, L., Gayer-Anderson, C., Rodriguez, V., La Cascia, C., ... \& Szoke, A. (2019). Jumping To Conclusions, General Intelligence, And Psychosis Liability: Findings From The Multicentric EU-GEI Case-Control Study. bioRxiv, 634352. https://doi.org/10.1101/634352

van Dael, F., Versmissen, D., Janssen, I., Myin-Germeys, I., van Os, J., \& Krabbendam, L. (2006). Data gathering: Biased in psychosis? Schizophrenia Bulletin, 32, 341-351. https://doi.org/10.1093/schbul/sbj021

van der Gaag, M., Schütz, C., ten Napel, A., Landa, Y., Delespaul, P., Bak, M., ... \& De Hert, M. (2013). Development of the Davos assessment of cognitive biases scale (DACOBS). Schizophrenia Research, 144(1-3), 63-71. https://doi.org/10.1016/j.schres.2012.12.010

Van Oosterhout, B., Krabbendam, L., De Boer, K., Ferwerda, J., Van der Helm, M., Stant, A. D., \& Van der Gaag, M. (2014). Metacognitive group training for schizophrenia spectrum patients with delusions: a randomized controlled trial. Psychological medicine, 44(14), 3025-3035. https://doi.org/10.1017/S0033291714000555

Woodward, T. S.,Mizrahi, R.,Menon, M., \& Christensen, B. K. (2009). Correspondences between theory of mind, jumping to conclusions, neuropsychological measures and the symptoms of schizophrenia. Psychiatry Research, 170(2-3), 119-123. https://doi.org/10.1016/j.psychres.2008.10.018

Woodward, T. S., Munz, M., LeClerc, C., \& LeComte, T. (2009). Change in delusions is associated with change in ,jumping to conclusions“. Psychiatry Research, 170, 124-127. https://doi.org/10.1016/j.psychres .2008 .10 .020

Young, H. F., \& Bentall, R. P. (1997). Probabilistic reasoning in deluded, depressed and normal subjects: Effects of task difficulty and meaningful versus non-meaningful material. Psychological Medicine, 27, 455-465. https://doi.org/10.1017/S0033291796004540

Zawadzki, J.A., Woodward, T.S., Sokolowski, H.M., Boon, H.S., Wong, A.H., \& Menon, M., (2012). Cognitive factors associated with subclinical delusional ideation in the general population. Psychiatry Research, 197 , 345-349. https://doi.org/10.1016/j.psychres.2012.01.004

Petra Šustová, katedra psychologie, Filozofická fakulta, Univerzita Karlova v Praze; Národní ústavduševniho zdraví, Klecany,e-mail: petra.sustova@nudz.cz

Mabel Rodriguez, katedra psychologie, Filozofická fakulta, Univerzita Karlova v Praze; Národní ústavduševního zdraví, Klecany,e-mail:mabel.rodriguez@nudz.cz 